\title{
RKCL4875
}

\section{ACID AND SUPERACID SOLIDS FOR THE TRANSFORMATION OF $n$-BUTANE}

\author{
Alcineia Conceição Oliveira ${ }^{a^{*}}$, Nadine Essayem ${ }^{\text {b }}$, Alain Tuel $^{\mathrm{b}}$, \\ Jean-Marc Clacens ${ }^{\mathrm{b}}$ and Younes Ben Taârit ${ }^{\mathrm{b}}$ \\ ${ }^{a}$ Instituto de Química, UFBA, Campus Universitário de Ondina, 40170-290, Salvador, Ba, Brazil \\ ${ }^{\mathrm{b}}$ Institut de Recherches sur la Catalyse, CNRS, Villeurbanne, France
}

Received April 26, 2006, accepted May 11, 2006

\begin{abstract}
Acid and superacid solids were evaluated in $n$-butane isomerization to produce isobutane. The combined dealumination and sulfatation of the starting $\mathrm{H}$ mordenite zeolite improves the activity and selectivity of the catalyst.

Keywords: Isobutane, mordenite, sulfatation, dealumination
\end{abstract}

\section{INTRODUCTION}

Isobutane is one of the most important basic chemicals in the modern petrochemical industry, extensively used for the production of methyl tert-butyl ether and ethyl tert-butyl ether which are used as oxygenate booster additives in the new reformulated gasoline $[1,2]$.

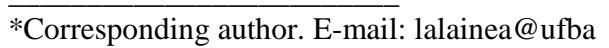


The skeletal isomerization of $n$-butane is the main route to obtain isobutane, with a worldwide production reaching millions of tonnes per year [1-4]. Inorganic acids or Lewis acids have been employed as catalysts in direct transformation of $n$-butane. However, due to enviromental pollution concerns and also in order to solve the problems of corrosion, there is a strong incentive for developing non-contaminating solid catalysts [5].

Therefore, severals studies have reported different aspects on the use of solid acids as heterogeneous catalysts for this reaction [3-6]. A wide range of substances, particulary bifunctional $\mathrm{Pt}-\mathrm{AlCl}_{3} /$ alumina, sulfate metals oxides, zeolites and zeotypes are able to catalyze the $n$-butane transformation, but sulfated zirconia (SZ) has been recognized as better than any other known catalysts since it has very strong acid sites whose conjugated anions can stabilize the unstable primary carbocation intermediate formed during the reaction at temperatures lower than $200^{\circ} \mathrm{C}[3,7]$. The reaction can also occur via a bimolecular mechanism over involving a $\mathrm{C}_{8}{ }^{+}$carbenium ion as intermediate [8].

The incorporation of metals and metal oxides on SZ strongly influence the catalytic behavior and improve its catalytic activity [3]. However, the strong catalyst decay is observed during the $n$-butane isomerizatin with SZ, due to the formation of coke. Thus, the use of monofunctional zeolite with strong acidity such as mordenite is an alternative way to produce isobutane, as reported in another work [9]. The present work deals with the development of acid and superacid catalysts based on modified dealuminated mordenites for the isomerization of $n$-butane to produce isobutane.

\section{EXPERIMENTAL}

The Na-Mor was provided by Société Chimique Grande Paroisse and converted into the acid form by three successive ion exchanges with a $1 \mathrm{~mol} \mathrm{~L}^{-1}$ ammonium chloride solution using $50 \mathrm{~mL}$ of the solution per gram of zeolite at $80^{\circ} \mathrm{C}$ for $8 \mathrm{~h}$. Dealumination was performed on the exchanged solid as proposed by Almanza et al. [10], using a steam partial pressure of $12.5 \mathrm{kPa}$, for approximately $9 \mathrm{~h}$. Then the solid was refluxed in hydrochloric acid $\left(3 \mathrm{~mol}\right.$. $\left.\mathrm{L}^{-1}\right)$ at $80^{\circ} \mathrm{C}$ for $1 \mathrm{~h}$ and subsequently washed in order to remove chloride species. A final calcination was performed under air at $500^{\circ} \mathrm{C}$ for $2 \mathrm{~h}$, leading to the dealuminated mordenite sample, labelled DM.

Sulfated dealuminated mordenite (SM) was prepared by treating $1 \mathrm{~g}$ of DM with a $0.1 \mathrm{~mol} \mathrm{~L}^{-1}$ sulfuric acid solution $(50 \mathrm{~mL}$ of solution for $1 \mathrm{~g}$ of $\mathrm{DM})$. Impregnation of the sulfate was carried out for stirring $4 \mathrm{~h}$ with a buffer $(\mathrm{pH}=3$ 5 ), followed by vacuum filtration and drying at $80^{\circ} \mathrm{C}$. The solid was then calcined under air flow at $500^{\circ} \mathrm{C}$ for $2 \mathrm{~h}$. 
Chemical analysis was performed in a Carry AAS/ ICP AES instrument. Each sample was dissolved in $\mathrm{HF}: \mathrm{HCl}$ solutions before measurement of the chemical composition. $\mathrm{X}$ ray diffraction (XRD) patterns were collected on a Shimadzu diffractometer with $\mathrm{CuK} \alpha$ radiation. ${ }^{27} \mathrm{Al}$ spectra NMR were obtained on a Bruker DSX400 spectrometer at the Magic Angle and a spinning frequency of $10 \mathrm{kHz}$. BET measurements were recorded on a Micromeritics ASAP 2002 equipment. Samples were first treated in vacuum to remove the gaseous impurities $\left(300^{\circ} \mathrm{C}, 6 \mathrm{~h}, 10^{-3}\right.$ Torr $)$ and the textural features were studied using nitrogen adsorption at $77 \mathrm{~K}$.

Calorimetry of ammonia adsorption was performed in a tubular cell preliminary heated at $400^{\circ} \mathrm{C}$ under vacuum for $2 \mathrm{~h}$. The cell was then introduced in a Setaram Soft Set 2000 calorimeter at $80^{\circ} \mathrm{C}$ and the experiment was performed. Successive ammonia injections were done until complete saturation of the sample.

$n$-Butane isomerization was used as test reaction in order to study the acidity of the solids. Prior to the reaction, the mordenites were embedded in an amorphous binder containing $30 \% \gamma-\mathrm{Al}_{2} \mathrm{O}_{3}$ and evaluated in the isomerization reaction. $100 \mathrm{mg}$ of the samples were placed in a tubular quartz reactor and heated at $400^{\circ} \mathrm{C}$, under air flow $\left(0.3 \mathrm{~L} \mathrm{~h}^{-1}\right.$ for $2 \mathrm{~h}$. The reaction was carried out at $200^{\circ} \mathrm{C}$ and $1 \mathrm{~atm}$, using a butane/nitrogen mixture $\left(5 \% n-\mathrm{C}_{4}\right.$ in $\mathrm{N}_{2}$, total flow rate $=1.28 \mathrm{~L} \mathrm{~h}^{-1}$ ) and the products were analyzed by a DELSI chromatograph with flame ionization detector coupled to a MERCK D2500 integrator.

\section{RESULTS AND DISCUSSION}

XRD patterns of mordenites show that the dealumination by steaming followed by acid leaching to prepare the dealuminated sample does not affect the crystallinity. Also, sulfatation of the latter, caused no significant loss of crystallinity, but generated structural defects in the materials by creating a secondary mesopore system proved by textural analysis.

The ${ }^{27} \mathrm{Al}$ NMR results shows a sharp resonance at $55 \mathrm{ppm}$, assigned to structural tetrahedral aluminium along with another large resonance at $0 \mathrm{ppm}$, corresponding to extra framework octahedral aluminium (EFAL). The large amount of non-structural aluminium species remaining in DM after acid leaching may be due to the fact that these species are still present in the narrow pores of the zeolite, and they are hardly accessible. Sulfatation increased the amount of EFAL species.

Calorimetry is a technique well suited to probe the acid concentration and strength on the surface of solid catalysts. Figure 1a shows that the DM sample possesses a large number of acid sites mainly with medium strength. We can also remark the difficulty for ammonia to access the acid sites at the beginning 
(a)

DM sample

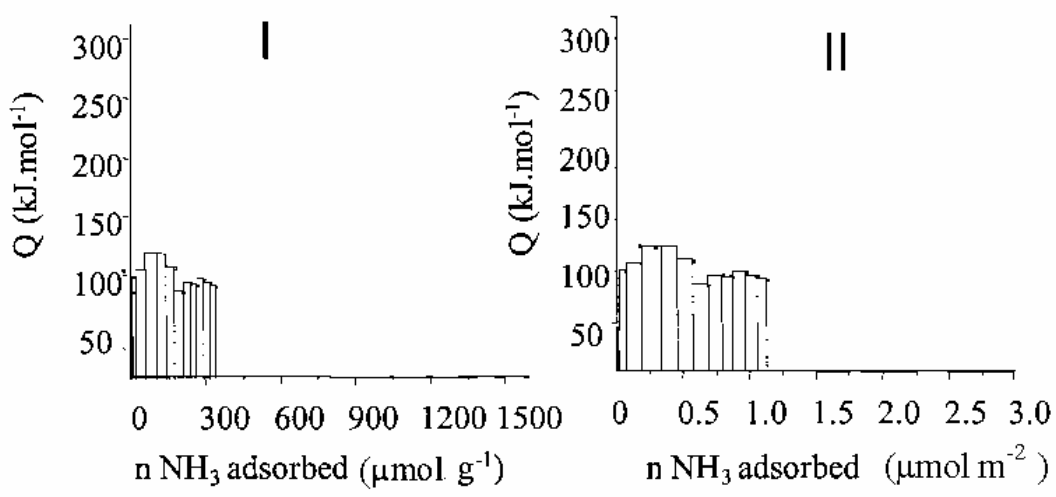

(b)

SM sample

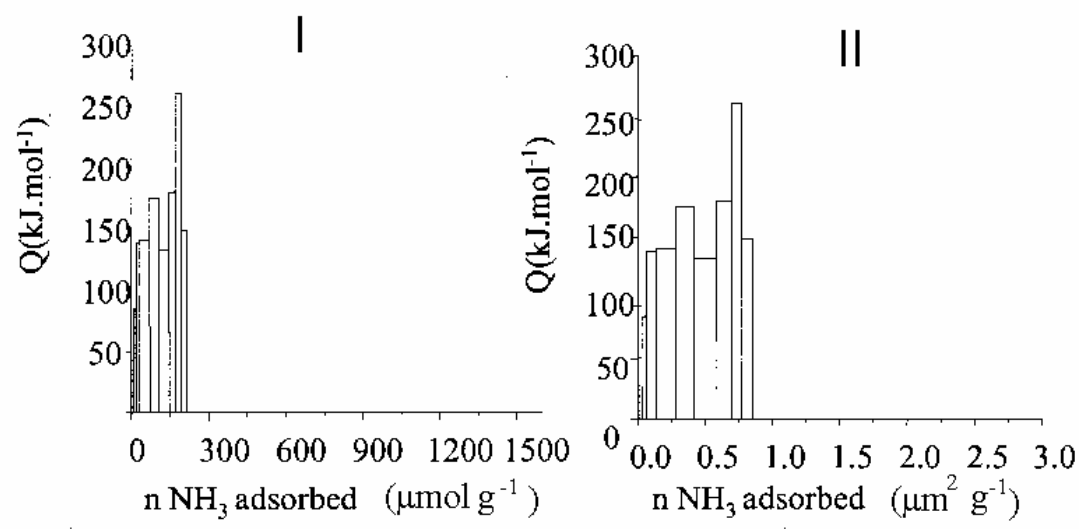

Fig. 1. Calorimetry diagrams of (a) dealuminated mordenite and sulfated dealuminated mordenite (b). Numbers I and II mean $\mu$ mol $\mathrm{NH}_{3}$ adsorbed per gram of catalyst $\mu \mathrm{mol} \mathrm{NH}$ and adsorbed $\mathrm{m}^{2}$ catalyst, respectively 
of the diagram, probably due to steric hindrance. Sulfatation provided acid sites of highest strength, but with a population not as homogeneous as in the case of the dealuminated sample (Fig. 1-b). EFAL species produced upon dealumination are related to Lewis acid sites, which can have medium or high strength, in agreement with other studies with mordenite [10,11]. Indeed, sulfatation created strong Lewis acid sites by generating more EFAl, in agreement with NMR results.

In line with these results, the Si/Al ratio (Table 1) increases from DM to SM because sulfatation removes aluminium from the sample, probably in the form of soluble aluminium sulfate. The elimination of part of extra framework aluminium by acid leaching provides an increase of the total number of the acid sites: some of the Brönsted acid sites, which were neutralized by cationic species become free. Upon sulfatation, more Lewis acid sites are formed and hence SM is shown to have more strong acid sites than DM.

\section{Table 1}

$\mathrm{Si} / \mathrm{Al}$ ratio, conversion of butane, rate of isobutane formation, selectivity to isobutane, propane, ethane, pentane and isopentane, $\mathrm{SiC}_{4}, \mathrm{SC}_{3}, \mathrm{SC}_{2}, \mathrm{SC}_{5}, \mathrm{SiC}_{5}$, respectively. Conditions: treatment: $2 \mathrm{~h}$ under air at $200^{\circ} \mathrm{C}$, Total flow rate $=1.3 \mathrm{~L} \mathrm{~h}^{-1} ; \mathrm{m}$ catalyst $=100 \mathrm{mg} .5 \% n-\mathrm{C}_{4}$ in $\mathrm{N}_{2}$; TR $=200^{\circ} \mathrm{C}$ $\mathrm{P}=1 \mathrm{~atm}$

\begin{tabular}{|c|c|c|c|c|c|c|c|c|}
\hline Sample & $\begin{array}{l}\mathrm{Si} / \mathrm{Al} \\
\text { ratio }\end{array}$ & $\% \mathrm{C}$ & $\begin{array}{c}\mathrm{iC}_{4} \text { rate } \\
\text { formation } \\
\left(\mathrm{mol} \mathrm{s}^{-1} \mathrm{~g}^{-1}\right) \\
\quad \times 10^{7}\end{array}$ & $\% \mathrm{~S}_{\mathrm{iC} 4}$ & $\% \mathrm{~S}_{\mathrm{iC} 3}$ & $\% \mathrm{~S}_{\mathrm{iC} 2}$ & $\% \mathrm{~S}_{\mathrm{C} 5}$ & $\% \mathrm{~S}_{\mathrm{iC5}}$ \\
\hline DM & 8 & 0.2 & 0.04 & - & - & - & - & - \\
\hline SM & 20 & 1.4 & 0.9 & 90.3 & 1.7 & 0.0 & 5.0 & 2.9 \\
\hline SZ & - & 12.7 & 6.8 & 91.4 & 3.0 & 0.1 & 3.5 & 2.0 \\
\hline
\end{tabular}

These results suggest that dealumination increases the number and strength of acid sites in the zeolite. The sulfatation also provides an increase of the acidity, but $\mathrm{SO}_{4}$ species can interact with EFAL species and partially block the porosity.

$n$-Butane isomerization, which requires strong acid sites, has been used as a test reaction to characterize the acidity of the samples. The total conversion of $n$-butane was calculated as: 


$$
\mathrm{C}(\mathrm{mol} \%)=\frac{(\mathrm{ni}-\mathrm{nf})}{\mathrm{ni}} \times 100
$$

where $n$ is the number of butane molecules in the feed.

Although DM sample contains a high density of acid sites, created upon dealumination that exposed more Brönsted acid sites to reactants, the $n$-butane conversion is very low $(0.2 \%)$, as seen in Table1. The conversion increases by a factor of seven for the sulfated dealuminated mordenite (SM). This can be attributed to the combination of strong acid sites and the mesoporous system, which permits the accessibility of the reagents to the active sites. However, in spite of its high acidity, SM shows only a low activity (1.4\%). The highest activity is observed with a reference sulfated zirconia sample, possessing a superacidity. The initial conversion level obtained with SZ sample reaches $12.7 \%$ under similar experimental conditions. Also, a $\gamma$-alumina and a sulfated $\gamma$-alumina samples were inactive, probably because they are only mildly acids with regard the strength required to initiate the isomerization.

The performance of the catalysts evaluated by means of rate of isobutane formation shows the superiority of sulfated zirconia $\left(6.8 \times 10^{-7} \mathrm{~mol} \mathrm{~s}^{-1} \mathrm{~g}^{-1}\right)$ compared with the modified mordenites. The selectivities obtained with DM are meaningless because the conversion level is too low. By contrast, the major product obtained with the sulfated catalysts is isobutane. In addition to this, byproducts as propane, isopentane and pentane were formed. The presence of these by-products evidenced the occurrence of the bimolecular dimerizationcracking pathway where $\mathrm{C}_{8}{ }^{+}$carbenium intermediate are formed and then cracked into lighter fragments, principally $\mathrm{C}_{3}$ and $\mathrm{C}_{5}$.

Although the reference SZ catalyst showed the best performance due to its strong acid sites, it also experienced a fast rate of deactivation. It can be related to acid sites being poisoned by coke precursors, probably as suggested by the dark grey color of the used sample. The acid sites present in the sulfated dealuminated mordenite were expected to catalyse the isobutane formation. However, the new sites generated by sulfatation were not able to maintain the $n$ butane activity, which rapidly decreased with time.

A part from these results, we conclude that the mesoporosity is created by dealumination of the mordenite framework. Subsequent sulfatation of the catalyst leads to additional dealumination and it considerably improves the conversion compared with a standard zeolite. Indeed, sulfate ions increase the strength and accessibility to acid sites, making this catalyst more active and selective compared with a dealuminated mordenite. $n$-Butane isomerization shows that SM has strong acid sites, whereas DM possess sites with a medium strength, in agreement with calorimetry of ammonia adsorption results. 


\section{CONCLUSIONS}

Dealuminated mordenite is practically inactive in the transformation of $n$ butane. Subsequent sulfatation of the catalyst leads to additional dealumination and to an increase of the conversion. Moreover, the product selectivity is changed, isobutane being the major product formed, meaning that sulfatation prevents secondary reactions. Moreover, additional products like isopentane, pentane are formed, indicating that other reactions involving $\mathrm{C}_{8}{ }^{+}$intermediate such as oligomerization-cracking can occur besides isomerization of $n$-butane.

The performance of a dealuminated sulfated mordenite results from a combination of strength and accessibility of acid sites, making this material a promising catalyst to produce isobutane. However its performace is lower than that of sulfated zirconia, a traditional catalyst used in this reaction.

Acknowledgement. The authors wish to thank CAPES/CNPq for A.C.O PhD scholarship as well as CNRS by funding of this research.

\section{REFERENCES}

1. A. Corma, A. Martinez: Catal. Rev. -Sci. Eng. 35, 483 (1993).

2. K. Arata: Appl. Catal., 146, 3 (1996).

3. A. Corma: Chem. Rev., 95, 559 (1995).

4. G.D. Yadav, J.J. Nair: Micropor. Mesopor. Mater., 33, 1 (1999).

5. P. Shing, E. Dai: Catal. Today, 26, 3 (1995).

6. M. Guisnet, Ph. Bichon, N.S. Gnep, N. Essayem: Topics in Catalysis, 11, 247 (2000).

7. V. Adeeva, G.D. Lei, W.M.H. Sachtler: Appl. Catal. A, 118, L11 (1994).

8. C. Bearez, F. Chevalier; M. Guisnet : React. Kinet. Catal. Lett., 22, 405 (1983).

9. A.C. Oliveira, A. Tuel, N. Essayem, J.M. Clacens, Y.B.Taârit, M.C. Rangel: Proc. 13rd Brazilian Congress on Catalysis/2nd. Mercocat, Foz do Iguaçu, Parana, Brazil, 2005, Vol. 3, p.763.

10. L.O Almanza: PhD Thesis, Université Claude Bernard-Lyon 1, France 1993.

11. I. Ivanova, V. Montouillout, C. Fernandez, O. Marie, J.P. Gilson: Micropor. Mesopor. Mater., 57, 297 (2003). 